\title{
Influence of Biogas Production on Bioremediation of Animal Manures
}

\author{
Essam Ibrahim Hammad, Mohamad R. Al-Agha, Yasser El-Nahhal* \\ Department of Environmental and Earth Sciences, Faculty of Science, The Islamic University, Gaza, Palestine \\ Email: *y_el_nahhal@hotmail.com
}

How to cite this paper: Hammad, E.I., Al-Agha, M.R. and El-Nahhal, Y. (2019) Influence of Biogas Production on Bioremediation of Animal Manures. American Journal of Analytical Chemistry, 10, 1-8. https://doi.org/10.4236/ajac.2019.101001

Received: December 3, 2018

Accepted: January 4, 2019

Published: January 7, 2019

Copyright $\odot 2019$ by author(s) and Scientific Research Publishing Inc. This work is licensed under the Creative Commons Attribution International License (CC BY 4.0).

http://creativecommons.org/licenses/by/4.0/

\section{cc) (i) Open Access}

\begin{abstract}
This study investigated the effect of biogas production on the removal hazardous waste properties. Biogas was produced from caw, chicken and mixed manure. Samples were taken before and after biogas production and tested for removal of total solid (TS), removal of chemical oxygen demand (COD), biological oxygen demand (BOD), and fecal coliform bacteria (FC). Results showed tremendous removal of the above mentioned parameters after biogas production. Chemical analysis of digestate indicates the advantages of using them as plant nutrients. Application of digestate in soil dramatically changed the chemical and physical properties of soil. It can be concluded that biogas production, is not only producing biogas but also removing waste parameters (TS, COD, BOD, FC) and producing plant nutrients.
\end{abstract}

\section{Keywords}

Biogas Production, Removal of COD, BOD and/or TS

\section{Introduction}

Accumulation of animal manure may create environmental problems such as air contamination [1], soil contamination [2], and water contamination [3] [4]. It became a potential beading site for fly and other insects. Remediation of waste becomes a pressing environmental problem in Gaza. Several attempts have been tested for bioremediation of waste. This included the use of cyanobacterial mats for bioremediation of chemical wastes [5]-[11], use of sand filter [12], land fills [13], incineration of wastes [14] and composting of organic wastes [15]. So far, the cyanobacteria were able to use the organic pollutants as a source of carbon, whereas sand filter was able to reduce biological and chemical oxygen demand for wastewater and provided good quality wastewater.

The abovementioned studies were limited to waste management in general; it 
did not deal with the influence of biogas production on bioremediation processes. So far, influence of biogas production on bioremediation processes remains poorly investigated or it is still in the primary stages. The authors of this study devoted their efforts to investigate the rule of biogas production on the bioremediation process.

\section{Materials and Method}

Biogas production process was operated as described recently [16]. On this regards, the remaining material in the digestion tank was tested for physico-chemical changes and compared with the original materials.

\subsection{Sampling of Digestant}

Digestate samples were taken only one time before operating the biogas production system. Then samples were collected each two days after operating the biogas production system during a period of 28 days of biogas production.

\subsection{Determination of Physico-Chemical Properties}

Determination of acidity $(\mathrm{pH})$, electric conductivity (EC), total solid (TS), chemical oxygen demand (COD), biological oxygen demand (BOD), phosphates $\left(\mathrm{PO}_{4}\right)$, sulfate $\left(\mathrm{SO}_{4}\right)$ and cations as mentioned previously [6] [7] [17]. All the parameters were analyzed and determined according to standard methods. Following the same procedure $\mathrm{Na}^{+}, \mathrm{K}^{+}, \mathrm{Mg}^{++}, \mathrm{Ca}^{++}$, and $\mathrm{NO}^{-}$, were determined before and after biogas production in manure. Analysis before biogas production was performed to a representative manure sample (1L sample in triplicate) collected after complete mixing and homogenization, was done on the next day of sample collection.

\subsection{Application of Digested Manure in Agriculture as Fertilizer}

Lettuce seedlings were purchased from a certified seedling production house. The seedlings were sown in plastic pots $10 \mathrm{~L}$ capacity each, having four halls in the bottom to allow water drainage movement. Each plastic pot contained $9 \mathrm{~kg}$ sand soil collected from an agricultural area having a history of free using organic fertilizers.

The experimental design included three treatments as follows: treatment 1 includes lettuce seedling sown in 5 plastic pots and receiving only fresh water, this treatment acts as control sample, treatment 2 includes lettuce seedlings sown in 5 plastic pots and receiving fresh manure (before biogas production), treatment 3 includes lettuce seedling sown in plastic pots receiving digested manure. The quantity of manure tested corresponded to the rate of $1 \mathrm{~kg} / \mathrm{m}^{2}$ of soil according to the recommendation of ministry of agriculture [18].

Percentage of lettuce was calculated by measuring fresh weight of lettuce after three weeks of sowing and taken as indicators of growth [19] or growth inhibition [20]. 


\subsection{Statistical Analysis}

Percentage of remediation was calculated by comparing the values at the beginning with that at the end of experiment. Large differences indicate best removal of corresponding pollutants. Average and standard deviation were calculated to each treatment. t-test was used to detect differences among treatment at p-value $=0.05$. Low value of standard deviation indicates homogenization and accuracy of the work. We included error bars in the figures where applicable. An overlapping of error bars indicates no significant differences. We also added letters in tables to indicate similarity of results.

\section{Results}

\subsection{Profile of Acidity ( $\mathrm{pH}$ ) in the Digestion Units}

$\mathrm{pH}$ profiles of daily measurements of manure during the gas production period are shown in Table 1. It has been shown that cow manure, chicken manure and mixed manure have the following $\mathrm{pH}$ ranges during biogas production; (7.98 \pm $0.02)-(7.58 \pm 0.01),(8.50 \pm 0.01)-(8.20 \pm 0.02)$ and $(7.97 \pm 0.01)-(7.50 \pm 0.03)$ respectively.

It can be seen that all $\mathrm{pH}$ ranges declined to a more acidic value during the biogas production regardless to the alkalinity range.

\subsection{Removal of Total Solid (TS)}

Percentage of TS removal of the manures is presented in Figure 1. It can be noticed that percentage removal TS are above $80 \%$ at all tested manure but the highest removal was observed with chicken manure followed by mixed one. The lowest removal was with cow manure. This indicates that TS value is being consumed during biogas production.

\subsection{Electric Conductivity (EC) Measurements}

Measured values of EC in manure are presented in Figure 2. The values are increased gradually and reached the maximum after 28 day of operation. This data indicates that manure suspension became more ionic during the biogas production. This property is increased by time. This suggests that the large insoluble molecules turned to be destroyed to many small molecules due to chemical and biochemical reactions during biogas production. This resulted in production of ionic molecules that increased EC values.

Table 1. Fecal coliform counts in manures CFU/ $100 \mathrm{ml}$.

\begin{tabular}{cccc}
\hline \multirow{2}{*}{ Samples } & \multicolumn{2}{c}{ Biogas production } & \% Removal \\
\cline { 2 - 3 } & Before & After & $>>98$ \\
\hline Cow manure & 400 & 2 & $>98$ \\
Chicken manure & 400 & 6 & $>98$ \\
Mixture manure & 520 & 3 & \\
\hline
\end{tabular}




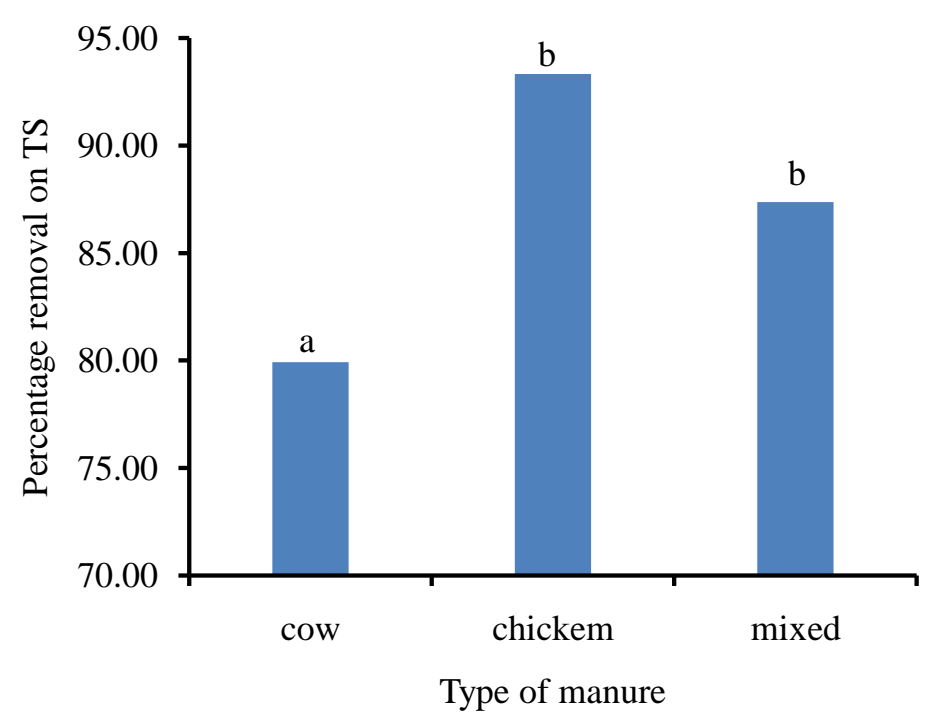

Figure 1. Percentage of TS removal during biogas production. Columns have the same letter are not significantly different at $\mathrm{p}$-value $=0.05$.

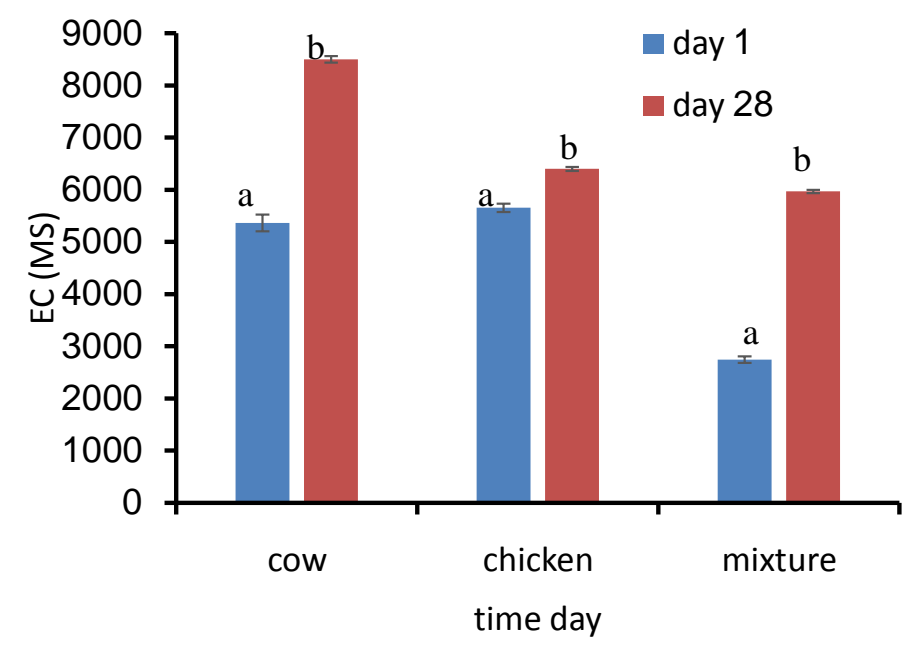

Figure 2. EC profile during biogas production. Values are average of three replicates of each treatments.

\subsection{Percentage Removal of COD and BOD}

Removal of COD and BOD from animal manures is presented in Figure 3. It can be noticed that percentage removal of COD from animal manures did not exceed $50 \%$ in all types. On the other hands BOD removal was in a similar range. However, removal of COD and BOD were lowest in chicken manure and highest in cow and mixed manure. Statistical analysis indicates significant difference in percentage removal of COD and BOD in different type of manure. These data indicated that biogas production generated a bioremediation process of manure.

\subsection{Microbiology Analysis}

Fecal coliform bacteria (FC) found in the manure before and after biogas production is show in Table 1. 


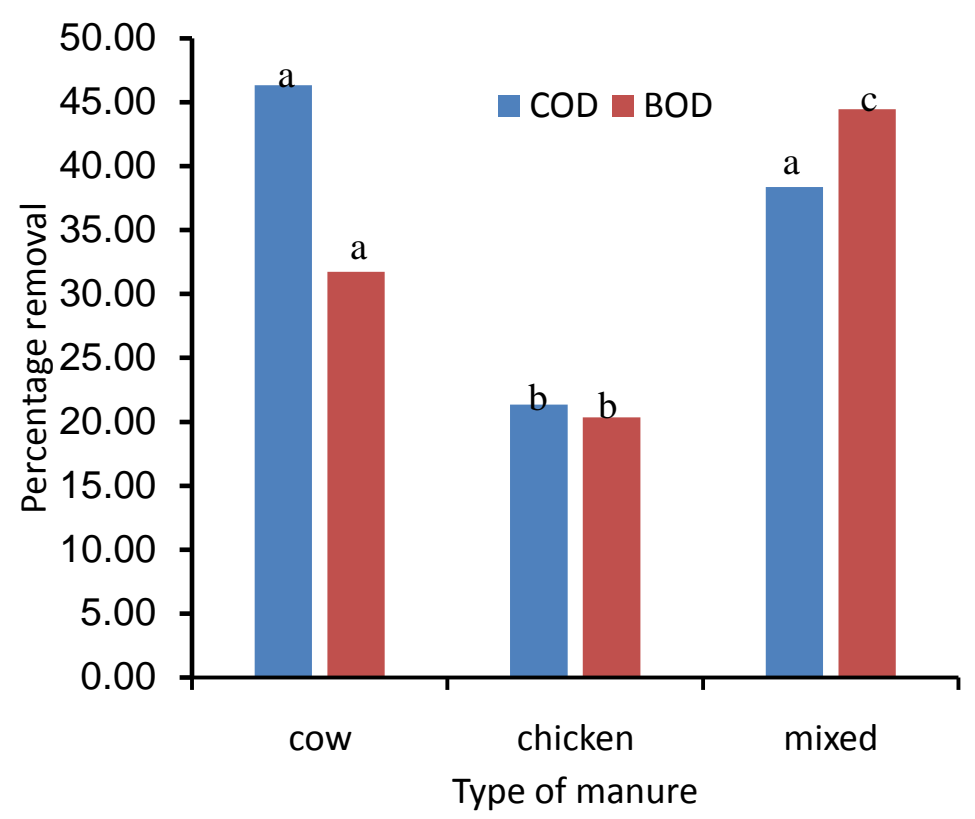

Figure 3. Percentage removal of COD and BOD in different manure. Parameter has same letter is not significantly different at $\mathrm{p}$-value $=0.05$.

\subsection{Influence of Digestate in Soil Properties}

Chemical changes on soil properties as a result of digestate application are shown in Table 2.

So far the tested parameters are tremendously increased in soil due to addition of digestate after biogas production except $\mathrm{pH}$ value reduced to a lower $\mathrm{pH}$.

The mechanical analysis of soil showed the following constituents: clay $17.5 \%$; silt $1.25 \%$, and sand $81.25 \%$. Due to these properties soil has a texture of sandy loam with a bulk density of $1.51 \mathrm{~g} / \mathrm{cm}^{3}$. The increased values of the tested parameters indicate the changes of soil properties to suit the growth of different plants. Recent published work [16] showed the advantages of using digestate as fertilizer.

\section{Discussion}

The data in Figure 1 clearly show percentage removal of TS. It is obvious that the highest removal was observed in chicken manure followed by mixed manure. The lowest removal was with caw manure. The explanation of these results is that chicken manure contained high fraction of organic nitrogen such protein, polypeptide and amino acids which can easily be degraded to ammonia by denitrifying bacteria. Cow manure contained high fraction of cellulose due the food nature of cows. Cellulose degradation is a little bit slower than protein, accordingly low removal TS was observed. This explanation is in accordance with previous reports [5] [21] [22] which revealed faster biodegradation of organic nitrogen containing compounds. They also revealed that denitrifying bacteria has an active rule in the bioremediation process.

The data in Figure 2 clearly show the increase of EC values from the $1^{\text {st }}$ day up 
Table 2. Parameters of Soil analysis before and after addition of slurry.

\begin{tabular}{ccc}
\hline Tested parameter & Before digestate & After digestate \\
\hline Water holding capacity (\%) & 17.5 & 18.6 \\
pH & 7.39 & 7.37 \\
EC (ms/cm) & 2.53 & 6.54 \\
sodium (PPM) & 25.7 & 172.7 \\
Calcium + Magnesium (mg/l) & 2.18 & 10.23 \\
Chloride (mg/l) & 3.59 & 14.9 \\
Nitrate (PPM) & 0.06 & 74.96 \\
Phosphorus (PPM) & 35 & 91.1 \\
Potassium (PPM) & 1.92 & 17.4 \\
\hline
\end{tabular}

to $28^{\text {th }}$ day after biogas production. The increases of EC values indicate the degradation of organic molecules to ionic molecules due to bacterial activity. The highest EC value was obtained with caw manure compared to chicken and mixed manure. The explanation of these results is that cellulose molecules can be degraded to fatty acid as in caw manure, whereas in chicken and mixture the protein compounds can produce amino acids on the biodegradation. These acids have buffering capacity in the solution so that increased acidity may inhibit the biodegration so that production of more acids is stopped. On the other hand fatty acids produced from cellulose biodegradation have no acid buffering capacity accordingly larger EC values were obtained with cow manure. This is in accordance with a previous report [22] which provides similar explanation for other cases. On the other hand percentage removal of COD was high in cow manure followed by mixed manure; the lowest removal was with chicken manure. Moreover, BOD removal was highest in mixed manure and lowest removal was with chicken manure. The explanation of these results is that cellulose molecules or polysaccharide molecules can easily be oxidized more than protein molecules as in chicken manure. Similar explanation was given for waste water treatment [14] [23]. In addition, percent removal of FC exceeds $98 \%$ in all cases, indicating full destruction FC community in the manure. The explanation of these results is that the biodegradation of manure components produced toxic metabolites that destroy the FC community in the manure. Similar explanation was given by Safi et al. [8].

Furthermore, analysis of soil samples before and after digestate application (Table 2), indicates the production of plant nutrients due to biogas production. Furthermore, recent application of manure increased agriculture yield and quality $[16]$.

\section{Conclusion}

The study revealed high percentage of TS removal in all type of tested manure. Percentage removal exceeds $80 \%$ in all cases. On the other hands EC values in- 
creased after biogas production indicating the production of ionic forms during the production of biogas. In addition COD and BOD removal was in the range of $20 \%-50 \%$, indicating low and/or slow removing process. On the other hands FC removal was above $90 \%$. An interesting outcome of the study is the production of plant nutrients during biogas production. It can be concluded that biogas production, is not only producing biogas but also removing waste parameters (TS, COD, BOD, FC) and producing plant nutrients.

\section{Conflicts of Interest}

The authors declare no conflicts of interest regarding the publication of this paper.

\section{Acknowledgements}

Prof Dr El-Nahhal Thanks AvH foundation for research stay in Berlin.

\section{References}

[1] Bornstein, R., Safi, J., El-Nahhal, Y., Isaac, J., Rishmawi, K., Luria, M., Mahrer, Y., Ranmar, D. and Weinroth, E. (2001) Transboundary Air-Quality Effects from Urbanization. UJSU Report to USAID-Merc.

[2] Heinze, S., Chen, Y., El-Nahhal, Y., Hadar, Y., Jung, R., Safi, J., Safi, M., Tarchitzky, J. and Marschner, B. (2014) Small Scale Stratification of Microbial Activity Parameters in Mediterranean Soils under Freshwater and Treated Wastewater Irrigation. Soil Biology and Biochemistry, 70, 193-204. https://doi.org/10.1016/j.soilbio.2013.12.023

[3] Al-Arifi, S.N., Al-Agha, R.M. and El-Nahhal, Z.Y. (2013) Hydrogeology and Water Quality of Umm Alradhma Aquifer, Eastern Saudi Arabia. Journal of Environment and Earth Sciences, 3, 118-127.

[4] Al-Arifi, S.N., Al-Agha, R.M. and El-Nahhal, Z.Y. (2013) Environmental Impact of Landfill on Groundwater, South East of Riyadh, Saudi Arabia. Journal of Natural Sciences Research, 3, 222-242.

[5] Abed, M.A., Safi, M.N., Köster, J., Beer, D., El-Nahhal, Y, Rullkötter, J. and Garcia-Pichel, F. (2002) Microbial Diversity of a Heavily Polluted Microbial Mat and Its Community Changes Following Degradation of Petroleum Compounds. Applied Environmental Microbiology 68, 1674-1683. https://doi.org/10.1128/AEM.68.4.1674-1683.2002

[6] El-Nahhal, I., Al-Najar, H. and El-Nahhal, Y. (2014) Physicochemical Properties of Sewage Sludge from Gaza. International Journal of Geosciences, 5, 586-594. https://doi.org/10.4236/ijg.2014.56053

[7] El-Nahhal, I., Al-Najar, H. and El-Nahhal, Y. (2014) Cations and Anions in Sewage Sludge from Gaza Waste Water Treatment Plant. American Journal of Analytical Chemistry, 5, 655-665. https://doi.org/10.4236/ajac.2014.510073

[8] Safi, J., Awad, Y. and El-Nahhal, Y. (2014) Bioremediation of Diuron in Soil and by Cyanobacterial Mat. American Journal of Plant Sciences, 5, 1081-1089. https://doi.org/10.4236/ajps.2014.58120

[9] El-Nahhal, Y. and Hamdona, N. (2015) Phytotoxicity of Alachlor, Bromacil and Diuron as Single or Mixed Herbicides Applied to Wheat, Melon, and Molokhia. 
SpringerPlus, 4, 367. https://doi.org/10.1186/s40064-015-1148-7

[10] EL-Nahhal, Y., Kerkez, M.F.S. and Abu Heen, Z. (2015) Toxicity of Diuron, Diquat and Terbutryn Cyanobacterial Mats. Ecotoxicology and Environmental Contamination, 10, 71-82. https://doi.org/10.5132/eec.2015.01.11

[11] El-Nahhal, Y. and Hamms, S. (2017) Effects of Bromacil, Malathion and Thiabendazole on Cyanobacteria Mat Growth. International Journal of Applied ScienceResearch and Review, 4, 1.

[12] El-Nahhal, Y. Omran El-Dahdouh and Anajjar Husam (2017) Influence of Sand Filter in Wastewater Treatment (a Case Study in Gaza City, Gaza Strip Wastewater Treatment Plant). Desalination and Water Treatment, 89, 118-126. https://doi.org/10.5004/dwt.2017.21398

[13] Liu, S.J., Xi, B.D., Qiu, Z.P., He, X.S., Zhang, H., Dang, Q.L., Zhao, X.Y. and Li, D. (2019) Succession and Diversity of Microbial Communities in Landfills with Depths and Ages and Its Association with Dissolved Organic Matter and Heavy Metals. Science of the Total Environment, 651, 909-916. https://doi.org/10.1016/j.scitotenv.2018.09.267

[14] Ji, L.J., Lu, S.Y., Yang, J., Du, C.C., Chen, Z.A., Buekens, A. and Yan, J.H. (2016) Municipal Solid Waste Incineration in China and the Issue of Acidification: A Review. Waste Management \& Research, 34, 280-297.

https://doi.org/10.1177/0734242X16633776

[15] Kaschl, A., El-Nahhal, Y., Abu Mourad, T., Tubail, Kh., Safi, J., Hadar, Y., Chen, Y. and Roemheld, V. (1998) Long Term Field Experiment to Examine the Agricultural Application of Municipal Solid Waste Compost in Gaza Strip. Proceedings of Verband Deutscher Landwirtschaftlicher Untersuchungsund Forschungsanstalten, Eiladung, KongreBband, 251-254.

[16] Hammad, E., Al-Agha, M.R. and El-Nahhal, Y. (2018) Enhancing Biogas Production: Influence of Mixing Cow and Chicken Manures. Energy and Power Engineering, 10, 383-397. https://doi.org/10.4236/epe.2018.108024

[17] El-Nahhal, Y., Safi, M., Tubail, K. and Safi, J. (2013) Effect of Treated Wastewater Irrigation on Plant Growth and Soil Properties in Gaza Strip Palestine. American Journal of Plant Science, 4, 1736-1743. https://doi.org/10.4236/ajps.2013.49213

[18] Ministry of Agriculture (2015) Annual Report.

[19] El-Nahhal, Y., Nir, S., Polubesova, T., Margulies, L. and Rubin, B. (1998) Leaching, Phytotoxicity and Weed Control of New Formulations of Alachlor. Journal of Agricultural Food Chemistry, 46, 3305-3313. https://doi.org/10.1021/jf971062k

[20] El-Nahhal, Y., EL-dahdouh, N., Hamdona, N. and Alshanti, A. (2016) Toxicological Data of Some Antibiotics and Pesticides to Fish, Mosquitoes, Cyanobacterial Mats and to Plants. Data in Brief, 6, 871-880. https://doi.org/10.1016/j.dib.2016.01.051

[21] El-Nahhal, Y., Awad, Y. and Safi, J. (2013) Bioremediation of Acetochlor in Soil and Water Systems by Cyanobacterial Mat. International Journal of Geosciences, 4, 880-890. https://doi.org/10.4236/ijg.2013.45082

[22] Safi, J., El-Nahhal, Y. and Safi, M. (2018) Particle Size Distribution and Hydraulic Conductivity in Coastal Non-Agricultural Land in Gaza Coastal Plain. International Journal of Geosciences, 9, 619-633. https://doi.org/10.4236/ijg.2018.910037

[23] El-Nahhal, Y., El-Dahdouh, O. and Al-Najar, H. (2017) Influence of Sand Filter in Wastewater Treatment (a Case Study in Gaza City, Gaza Strip Wastewater Treatment Plant). Desalination and Water Treatment, 89, 118-126.

https://doi.org/10.5004/dwt.2017.21398 